\title{
Analysis of Capital Control Policies in China
}

\author{
Liu Yang \\ School of Economics, Jinan University, Guangzhou, China \\ Email: suny_2020@163.com
}

How to cite this paper: Yang, L. (2020) Analysis of Capital Control Policies in China. American Journal of Industrial and Business Management, 10, 492-505. https://doi.org/10.4236/ajibm.2020.102033

Received: February 4, 2020

Accepted: February 25, 2020

Published: February 28, 2020

Copyright $\odot 2020$ by author(s) and Scientific Research Publishing Inc. This work is licensed under the Creative Commons Attribution International License (CC BY 4.0).

http://creativecommons.org/licenses/by/4.0/

Open Access

\begin{abstract}
With the continuous development of economic globalization and the liberalization of China's capital account, and the scale and frequency of international capital flow are constantly increasing. These cross-border capital flows not only promote the domestic economic development, but also bring many potential risks to the domestic economic and financial system. Many international organizations' and countries' views on the capital control also changed, and put forwarded the policy framework of capital flow management, including macro prudence and capital flow management. Furthermore, the capital control policy itself and its effect also become the focus of governments and the academia. Based on the establishment of monthly and quarterly capital control indicators in 1995-2018, this paper analyzed the characteristics and trends of China's capital control policy. The results show that: the intensity of China's capital control policy is fluctuating and decreasing, and the restrictions are gradually relaxed, and the development of economic globalization is obviously affected by domestic economic environment and international factors.
\end{abstract}

\section{Keywords}

Capital Control Policies, Capital Flow, Capital Account

\section{Introduction}

The meaning of capital control is a country's measures to control its international capital flow. It mainly refers to the policies and measures formulated by officials in each country to restrict capital account transactions as well as the payment and transfer of funds (IMF, 1991).

With the acceleration of economic and financial global integration, cross-border flow of capital between countries has become an irreversible trend, and the possible abnormal fluctuations of short-term capital flow will also bring challenges in the relevant countries. Faced with this situation, finding a effective way to adjust 
capital flow and to reduce the incidence of serious imbalances in income and expenditure caused by cross-border speculative capital flow, ensuring the stability of domestic investment, preventing capital outflow and stabilizing macroeconomics is a key issue for a country to maintain the development of economic in the context of globalization.

In addition, the emergence of the new impossible triangle has also made capital controls play a pivotal role in managing cross-border capital and the negative impact of its abnormal fluctuations.

Base on the above considerations, this article establishes monthly and quarterly indicator to measure capital control intensity and analyzes the characteristics and trends of the capital control intensity through a combination of qualitative and quantitative methods.

\section{Literature Review}

The intensity of capital control is an indicator to measure the openness of a country's capital account and the degree of freedom of capital flow. The measurement of the intensity of capital control is the basis of the analysis and research on these policies and their impact on international capital flow. However, there is no standard method to measure the intensity of capital control in the academic at present. The existing methods can be generally summarized as two categories which are de jure (legal indicators) and de fact (fact indicators).

For the legal indicators, scholars mainly use the classification information of the asset market and credit market provided in the annual exchange rate arrangement and control report issued by the International Monetary Fund to establish and measure the indicators according to a country's actual control situation of international capital flow, and the indicators are virtual variables. Epstein and Schor (1992) first used this method to describe the intensity of capital control. Schor used this method to establish the regulatory indicators of 16 OECD member countries in 1992, and proposed the meaning of 0 and 1 which are represent full liberalization and full regulation respectively for the first time.

After that, scholars tried to make the description of regulatory intensity more accurate by setting more detailed standards. Gwartney et al. (1996) used a more detailed market classification which divided the regulation into 13 categories and calculated the indicator of capital regulatory intensity under each category, while Jin (2004), Quinn and Toyoda (2007) thought that the only two standards $(0,1)$ can not reflect the change of intensity, so they set a more detailed standard for the evaluation range according to the content of the research. In the research, Jin (2004) adopted the evaluation standard of different capital transaction items with the evaluation range of $1,0.5$ and 1 according to the laws and regulations. Jin (2004) calculated the change of annual capital control intensity of China from 1995 to 2003. Quinn and Toyoda (2007) subdivided the evaluation range into five levels: $0,0.5,1,1.5$ and 2 with the two directions of inflow and outflow, they calculated a more comprehensive control intensity indicator-Quine indicator. 
Chinn and Ito (2008) further combined and optimized the above calculation methods, and established the Kaopen indicator which is commonly used in the current academic research on capital control. This indicator contains relevant data of 182 countries. Binici et al. (2010) further reclassified the asset market into six categories. To sum up, the measurement method of regulatory indicators has the same model basis that is based on the combing of laws and regulations, the difference lies in the combination of different classifications and evaluation ranges of research facts. These measurement methods can describe the intensity change of a country's policy on capital account. Table 1 shows the classification rules adopted by El-Shagi (2012) in the construction of capital control indicators in the study.

The fact indicator is to analyze the intensity of capital account control through some economic indicators. They think that these economic indicators as the result of the implementation of capital control policies can reflect the influence and change of the policies. It mainly includes three ways: saving rate-investment rate method, rate parity method and measurement method of cross-border capital flow. Therefore, the fact indicator measures the degree of capital account openness by one or more economic variables, and then represents the intensity of capital control accordingly.

The saving rate investment rate method first appeared in the study of capital control by Feldstein and Horioka (1980). The core assumption of this method is that when capital is completely liberalized, investment and saving in a country should show no correlation with each other. If there is a correlation between investment rate and saving rate, it shows the intensity of capital control policy in corresponding period. Jin (2004) used this method to test the impact of China's capital control in 1991-2003. She found that the correlation between investment rate and savings rate in China was stable at the level of over $70 \%$ in all periods. It was considered that China's capital control policies on international capital flow worked well in the selected period. However, this method has been questioned by many scholars for a long time, who believe that capital control cannot completely determine the changing relationship between investment and savings in a country. Bayoumi (1990) believed even if there are no restrictions on the international capital flow, investment and saving in a country may still show a correlation with each other.

This paper also uses the saving rate-investment rate method to analyze the correlation between China's savings rate and investment rate in 1995-2018, the result is showed in Table 2.

The calculation results are basically consistent with the research results of other scholars (Jin, 2004; Zeng, 2015, etc.). According to Table 2, it can be seen that the correlation coefficient between savings and investment is 0.80 in the whole selected period of 1995-2018 which indicates that there is a high degree of interaction between the two and capital control policies have a significant impact on cross-border capital flow in China. In the analysis of each interval period, we sets the time node at two special time points in 1997 and 2008 to observe the changes 
Table 1. The construction of the measure index of the intensity of capital control.

\begin{tabular}{|c|c|c|c|}
\hline \multicolumn{2}{|c|}{ Classification of capital control items } & \multirow{2}{*}{$\begin{array}{c}\text { Inflow } \\
\times\end{array}$} & \multirow[t]{2}{*}{ Outflow } \\
\hline Securities market (stock market, bond market & Non-residents buy locally & & \\
\hline and mutual investment securities) & $\begin{array}{l}\text { Sold or issued locally by } \\
\text { non-residents }\end{array}$ & & $x$ \\
\hline Other derivatives and related derivatives market & Residents buy overseas & & $\times$ \\
\hline Money market Instruments & $\begin{array}{c}\text { Sold or issued by residents } \\
\text { overseas }\end{array}$ & $x$ & \\
\hline$D$ & Residents to non-residents & & $x$ \\
\hline financial credit and credit guarantee related) & Non-residents to Residents & $x$ & \\
\hline \multicolumn{2}{|l|}{ Capital control index } & 13 & 13 \\
\hline
\end{tabular}

Notes: "X" means that there are no related policies on the project. Source: El-Shagi (2012) and Gou et al. (2012).

Table 2. Analysis of the relationship between savings and investment in China (1995-2018).

\begin{tabular}{|c|c|c|c|c|c|c|}
\hline Year & GDP & $\begin{array}{c}\text { Total } \\
\text { consumption }\end{array}$ & Total investment & $\begin{array}{l}\text { Consumpti } \\
\text { on rate }\end{array}$ & $\begin{array}{l}\text { Savings } \\
\text { rate }\end{array}$ & $\begin{array}{c}\text { Investment } \\
\text { rate }\end{array}$ \\
\hline 1995 & $61,339.90$ & $36,748.20$ & $25,470.10$ & 59.91 & 40.09 & 41.52 \\
\hline 1996 & $71,813.60$ & $43,919.50$ & $28,784.90$ & 61.16 & 38.84 & 40.08 \\
\hline 1997 & $79,715.00$ & $48,140.60$ & $29,968.00$ & 60.39 & 39.61 & 37.59 \\
\hline 1998 & $85,195.50$ & $51,588.20$ & $31,314.20$ & 60.55 & 39.45 & 36.76 \\
\hline 1999 & $90,564.40$ & $55,636.90$ & $32,951.50$ & 61.43 & 38.57 & 36.38 \\
\hline 2000 & $98,749.00$ & $61,516.00$ & $34,842.80$ & 62.30 & 37.70 & 35.28 \\
\hline 2001 & $109,027.99$ & $66,933.89$ & $39,769.40$ & 61.39 & 38.61 & 36.48 \\
\hline 2002 & $120,475.62$ & $71,816.52$ & $45,565.00$ & 59.61 & 40.39 & 37.82 \\
\hline 2003 & $136,613.43$ & $77,685.51$ & $55,963.00$ & 56.87 & 43.13 & 40.96 \\
\hline 2004 & $160,956.59$ & 87552.58 & $69,168.41$ & 54.40 & 45.60 & 42.97 \\
\hline 2005 & $187,423.42$ & 99357.54 & $77,856.82$ & 53.01 & 46.99 & 41.54 \\
\hline 2006 & $222,712.53$ & $113,103.85$ & $92,954.08$ & 50.78 & 49.22 & 41.74 \\
\hline 2007 & $266,599.17$ & $132,232.87$ & $110,943.25$ & 49.60 & 50.40 & 41.61 \\
\hline 2008 & $315,974.57$ & $153,442.49$ & $138,325.3$ & 48.56 & 51.44 & 43.78 \\
\hline 2009 & $348,775.07$ & $169,274.8$ & $164,463.22$ & 48.53 & 51.47 & 47.15 \\
\hline 2010 & $402,816.47$ & $194,114.96$ & $193,603.91$ & 48.19 & 51.81 & 48.06 \\
\hline 2011 & $472,619.17$ & $232,111.55$ & $228,344.28$ & 49.11 & 50.89 & 48.31 \\
\hline 2012 & $529,238.43$ & $261,832.82$ & $252,773.24$ & 49.47 & 50.53 & 47.76 \\
\hline 2013 & $592,963.20$ & $292,842.80$ & $288,214.21$ & 49.39 & 50.61 & 48.61 \\
\hline 2014 & 641280.60 & $328,896.10$ & $313,940.81$ & 51.29 & 48.71 & 48.96 \\
\hline 2015 & $685,992.90$ & $330,930.80$ & $339,919.91$ & 48.24 & 51.76 & 49.55 \\
\hline 2016 & $740,060.80$ & $356,316.30$ & $358,385.81$ & 48.15 & 51.85 & 48.43 \\
\hline 2017 & $820,754.30$ & $376,261.60$ & $413,158.51$ & 45.84 & 54.16 & 50.34 \\
\hline 2018 & $900,309.50$ & $410,986.90$ & $457,595.11$ & 45.65 & 54.35 & 50.83 \\
\hline \multicolumn{3}{|c|}{ Time Interval } & \multicolumn{4}{|c|}{ Correlation coefficient of investment rate-savings rate } \\
\hline \multicolumn{3}{|c|}{ 1995-1997 } & \multicolumn{4}{|c|}{0.75} \\
\hline \multicolumn{3}{|c|}{$1997-2004$} & \multicolumn{4}{|c|}{0.97} \\
\hline \multicolumn{3}{|c|}{$2005-2008$} & \multicolumn{4}{|c|}{0.85} \\
\hline \multicolumn{3}{|c|}{$2009-2018$} & \multicolumn{4}{|c|}{0.43} \\
\hline \multicolumn{3}{|c|}{$1995-2018$} & \multicolumn{4}{|c|}{0.80} \\
\hline
\end{tabular}


of the intensity of capital control before and after the financial crisis. It can be seen that the correlation coefficients of investment rate and saving rate in 1995-1997 and 1997-2004 are 0.75 and 0.97 respectively. The correlation coefficients of 1995-1997 and 1997-2004 are less than the whole period coefficient of 0.80, which shows that the correlation coefficients of countries in 1995-1997 are less than the whole period coefficient. This is because the restrictions on cross-border capital gradually relaxed, and the correlation coefficient between the two increased significantly around 1997. This is because after the outbreak of financial crisis, in order to prevent the further spread of the crisis and the vicious impact of China's economic and financial stability, China has intensified its supervision and tightened restrictions on cross-border capital flow. At this time, China's cross-border capital control is still relatively strict compared with other countries, so there is no large amount of short-term cross-border capital inflow at this time. After the crisis, China put forward the resolution about the process of capital liberalization, so the correlation coefficient of investment rate and savings rate was again reduced to 0.85 . After 2008, the correlation coefficient was significantly reduced to 0.43 because of the impact of China's continuous promotion of RMB internationalization and the previous development strategy of capital liberalization which relaxed many restrictions of cross-border capital. From the above analysis, we can see that China's capital control policy keeps the trend of continuous deregulation in the long run.

The rate parity method is based on the principle of no arbitrage, that is, under the condition of complete liberalization of the capital account, the domestic interest rate and the foreign interest rate of a country conform to the relationship of no arbitrage interest rate parity, and the restriction of the capital account will make the difference between them, which makes the domestic interest rate deviate from the non arbitrage interest rate. At the same time, the larger the deviation, the weaker the correlation, the stronger the control of the capital account. The method of using interest rate difference to examine the intensity of capital control in a country was first put forward in the research on the influencing factors of the relationship between German monetary interest rate and other monetary interest rates.

The capital flow method is to measure the openness of capital account according to the ratio of the flow capacity of international capital items to GDP, that is, to use the ratio of capital scale of each project to GDP so as to measure the openness and control intensity of the project. This method first appeared in the study of Kraay (1998). Kraay (1998) use the ratio of flow capacity of capital account to GDP to measure the openness of capital account, and calculated the capital control intensity of all countries publishing balance of payments statistics. Table 3 detailed reports the related information of two kinds of measurement method of capital flow.

In addition to the above three main measures of fact indicators, some research also uses other economic indicators such as stock openness, financial market openness and investment indicator. Bekaert, Harvey, \& Lundbald (2003), 
Table 3. Measurement method of capital flow.

\begin{tabular}{ccccc}
\hline Name & Source & Method & Year & Country \\
\hline Capital flow & Kraay (1998) & $\begin{array}{c}\text { Capital } \\
\text { flow/GDP }\end{array}$ & $1985-1997$ & 117 countries \\
\hline Capital stock & $\begin{array}{c}\text { Lane \& } \\
\text { Milesi-Ferreti } \\
(2001)\end{array}$ & $\begin{array}{c}\text { Capital } \\
\text { stock/GDP }\end{array}$ & 1970-1998 & $\begin{array}{c}70 \text { developed and } \\
\text { developing countries }\end{array}$ \\
\hline
\end{tabular}

Levine and Zervos (1998) make a comparative analysis on the intensity of capital control in emerging market countries and industrialized countries by stock market openness. Edison and Warnock (2003) measured a country's equity limit by 1-IFC investment indicator divided by IFC Global indicator, and then combed and calculated the capital account openness and relevant policies of 29 emerging market countries.

\section{Capital Control Policies in China}

In this part we will talk about capital control policies in China. The restriction of international capital is an important means to stabilize the domestic economy under the background of economic globalization. Especially after the financial crisis in 1997 and 2008, the international view of capital flow control is more acceptable and inclusive. In 2011, the IMF issued the report named recent experience of capital inflow management-possible regulatory policy framework, which formally recognized the necessity of implementing certain regulations on international capital for the first time. In 2014, ten countries of the European Union also reached an agreement to try to restrict the cross-border flow of "hot money" for financial speculation by means of financial transaction tax to prevent related financial risks.

Since the reform and opening up, China has also accumulated rich practical experience in international capital control. With the continuous development of domestic economy and globalization, the regulatory policies have obvious characteristics of different development stage and global economic background, the main focus and concept of China's capital control policy also changed accordingly. Combined with the division idea of foreign exchange system in China, capital control can also be divided into four stages accordingly.

The first stage is from 1978 to 1993. As the domestic market mechanism is just in its infancy, the current account and capital account items are strictly controlled in this period. The main targets of the control are also focused on attracting foreign investment, increasing the ability of export to earn foreign exchange, and supplementing the shortage of foreign exchange to provide more energy for the domestic economic development.

The second stage is from 1994 to 2000.During this period, the current account control is completely liberalized, but the capital account control is still relatively strict. 1994 is an important year for China's capital control policy reform. On January 1, 1994, China carried out the first exchange rate reform, canceling the 
original dual exchange rate system, and began to implement a managed floating exchange rate system. This is the first time for China to liberalize the control of international capital flow items. In December 1996, China realized that full convertibility of current items and completely liberalization of the restrictions on cross-border transactions related to current items lay a great foundation for the development of China's capital liberalization. Since the implementation of the Interim Provisions on the administration of domestic foreign exchange transfer in 1998, it has started to relax the control over international capital transactions in capital accounts gradually.

The third stage is from 2001 to 2016. During this period, the pace of liberalizing capital control is speeding up, and the balance of payments is officially regarded as one of the four major objectives of macroeconomic regulation and control. In 2001, China formally joined the WTO, and its contacts with other countries were more frequent and economic relations were closer, which greatly promoted the development of capital liberalization policy. In terms of capital market, qualified domestic investors were allowed to buy B shares in 2001,. In 2002 and 2006, qualified foreign institutional investors and domestic institutional investors were respectively allowed to open, and non-resident financial institutions were allowed to purchase A-shares and fixed income financial products invested by resident financial institutions in overseas securities markets within a certain limit. In 2011, the work of RMB qualified overseas investors was launched, allowing qualified relevant investors to use the RMB funds raised in Hong Kong to conduct securities investment business in China. From 2014 to 2016, the "Shanghai-Hong Kong stock connect" and "Shenzhen-Hong Kong stock connect" were launched respectively, and mutual recognition between Mainland and Hong Kong funds was implemented.

In terms of direct investment, in 2001 and 2002, qualified domestic investors were allowed to purchase foreign exchange to invest in national strategic projects and foreign aid projects, and foreign investment was allowed to enter several industries that were not previously allowed to open to them. In 2004, qualified domestic investors were allowed to invest in Hong Kong, Macao and overseas enterprises. From 2009 to 2015, a number of policies were introduced to expand the scale and source of funds for overseas loans, and to simplify relevant procedures as well as to support domestic enterprises to go abroad.

The fourth stage is from 2017 to now. In this period, in addition to the steady deregulation, the capital control policy has added the element of "macro prudential". At the 19th National Congress of the Communist Party of China in 2017, the two-in-one management framework of "macro prudential and micro regulatory" has been put forward. In the same year, we promoted the opening of domestic bond market through the implementation of "bond link", and further expanded the two-way opening of financial market through a series of new cross-border securities investment mechanisms. In 2016, the system of qualified foreign institutional investors (QFII and QFII) was reformed twice to further expand the openness of domestic capital market to foreign institutional investors. 
With regard to China's capital control tools, the IMF has made clear the definition of capital flow management measures (CFMS). It holds that capital control tools refer to a series of policy measures, including administrative means, tax and macro prudential policies which is aimed at restricting international capital flow and influencing their scale or structure. At present, the views of the academia on regulatory instruments are basically consistent with the definition of IMF (such as Zhang, 2016; Shusong Ba \& Qing Ba, 2019, etc.).

At present, the regulatory instruments adopted in China can be divided into two categories. The first category is the traditional regulatory instruments for the relevant exchanges involving residents or non residents of international capital flow, that is, the regulatory instruments are mainly based on the traders' residence, and the management measures include taxation, administrative control over trading activities, restrictions on the subject, amount or time limit of trading activities, etc. The second type is other regulatory tools that have been added to the consideration of macro prudential control. The main purpose of such control is not to limit the cross-border capital flow based on the traders' residence, but to focus more on the use of capital and can effectively reduce the potential threat to the stability of a country's domestic financial market. Therefore, unlike the first type of capital control policy, which is aimed at different places of residence, this kind of control tool is more aimed at the category of currencies. For example, the foreign debt management measures of foreign banks issued in China contains the restrictions on foreign currency by setting differential reserve rate to local currency and foreign currency.

\section{Indicator Construction and Calculation}

In the analysis of the regulatory policy in the previous section, it can be found that the capital control policy in China changes in different degrees every year, but Kaopen which is commonly used are less accurate in reflecting the changes of the capital control intensity. In order to better understand the changes of China's capital control policies and analyze the effect of policy implementation, this paper refers to the calculation method of capital control intensity indicator by Huang \& Wang (2010) and Gou et al. (2012) and calculate the monthly and quarterly capital control intensity indicators of China from December 1995 to December 2018, and the specific method is as follows:

Different from Gou et al. (2012) only considering the laws and regulations related to capital account, this paper holds that the implementation of capital control policy will not only affect the capital account, but also indirectly affect the capital flow of current account. Therefore, when combing the laws and regulations, all the laws and regulations that affect the capital flow are considered, but this will still be reflected in the capital account, so the scoring items are still classified according to the capital account sub items provided in the annual exchange rate arrangement and control report. The 11 major categories of sub items are "capital market securities", "money market instruments", "co-investment securities", "derivatives and other instruments", "commercial and financial credit", 
"guarantees, guarantees and financial support instruments", "outward direct investment", "foreign direct investment of direct investment", "liquidation of direct investment", "real estate transactions", "personal capital transactions" and are further divided into $38 \mathrm{sub}$ categories, and each sub category is given equal weight for scoring.

\section{1) Base time}

As the same with the assumption of Jin (2004) and Gou et al. (2012) this paper takes the year of 1977 which is the year before China's reform and opening up as the calculation base year. At this time, all capital items in China are under strict control.

\section{2) Scoring assignment criteria}

The scoring assignment standard of this paper range from 1 to 0 , and it is divided into four levels $1,0.75,0.25,0$. Higher values indicate higher regulatory intensity. 1 means full control, and the sub projects are strictly prohibited by laws and regulations or are prohibited in real economic exchanges despite no regulations. 0 means little control of sub items except for the required approval procedures or authenticity verification, and there are basically no other provisions to restrict the transaction activities under the project. 0.25 refers to the transaction activities within the scope of provisions shall be restricted. 0.75 refers to most of the transactions or transaction activities under the sub projects shall be restricted.

In this paper, 220 regulations related to capital flow issued by the authority are used as the basis for scoring. If there is a significant restriction in this period compared with the previous period, the assignment will reduce by -0.75 points. If there is a inconsequential restriction in this period compared with the previous period, the assignment will reduce by -0.25 points. If there is no change, then the assignment is 0 point. The inconsequential restriction increase (decrease) here refers to: the laws or regulations promulgated or repealed involve the change of trading activity quota, adjustment of time, implementation of temporary regulations, while the restricted trading object has no change; the significant restriction increase (decrease) refers to: the laws and regulations promulgated or repealed involve the change of the affected trading subject or the obvious change of the scope of the trading object. The above definition method adopted in this paper is mainly based on the definition proposed by the State Administration of Foreign Exchange. The change of the scope of the transaction subject can be considered as the obvious change of the limitation of the sub project, which means that the project changes from a more restrictive situation to a less restrictive situation.

When sorting out laws and regulations, this paper think that if the implementation time is specified in the regulations, the change of capital control intensity will be calculated at the specified time, and if there is no specified time, this paper think when the promulgation time of laws and regulations is before the 15th day of the month, it will be considered as the implementation of this month, and when the laws and regulations issued after the 15th day of the month, it will be 
considered as the implementation of next month. In addition, the capital control intensity indicator in this paper is only a relative indicator. That is to say, although it is assumed that when the calculation result of sub project is 1 , it means that the project is under full control, but when the calculation result of subproject is 0 , it does not mean that the project is under full free trade or full liberalization. Different from Jin (2004), Huang \& Wang (2010) and Gou et al. (2012), this paper distinguishes the flow into outflow and inflow projects. The trend and direction of the change of the intensity of capital account control in China can be observed and analyzed through the change of the calculation results.

\section{Analysis and Conclusion}

\subsection{The Analysis of the Result}

Based on the indicator construction and calculation described in the previous section, this paper combs, classifies and scores 220 regulations, and calculates the monthly and quarterly control intensity indicators of China from December 1995 to December 2018, and compares the calculation result indicators with the actual development of China's capital policies. The calculation results are shown in Figure 1 and Figure 2 respectively.

Figure 1 shows the calculation results of monthly capital control intensity indicator. It can be seen that China's capital control showed a fluctuated downward trend from December 1995 to December 2018. This is because China has adhered to promote the strategy of international development of Renminbi. Based on the growth of domestic economy and financial market, we have steadily and gradually liberalized limitation of the capital flow to ensure that the capital liberalization can promote the development and stability of domestic economic, and will not bring potential negative effects to the domestic economy.

Figure 2 shows the calculation results of quarterly capital control intensity indicator. After quarterly smoothing, the trend of capital control remains the same. From the calculation results, it can be seen that China's capital control intensity has increased significantly in 1996-1999, 2007-2009 and 2017-2018, which is in line with the two financial crises and the trade friction in 2018. In order to prevent the sudden abnormality of capital in China and the negative impact of volatility on the domestic economy, the limitation of international capital has been limited and tightened. In addition, the change interval of Figure 1 and Figure 2 can be roughly divided into four stages: 1995-1999, 2000-2006, 2007-2015 and 2016-2018.

During the period of 1995-1998, the intensity of capital control in China began to decline in general, then had a rise in 1997. In 1996, China accepted the obligation of the Eighth Article of IMF, canceling all the restrictions on payment and transfer of current account gradually, and further relaxed the control of cross-border capital flow. This laid the foundation for the opening of capital account. However, in 1997, the Asian financial crisis broke out, which made some Asian countries with high-speed economic development begin to experience sharp economic depression, 


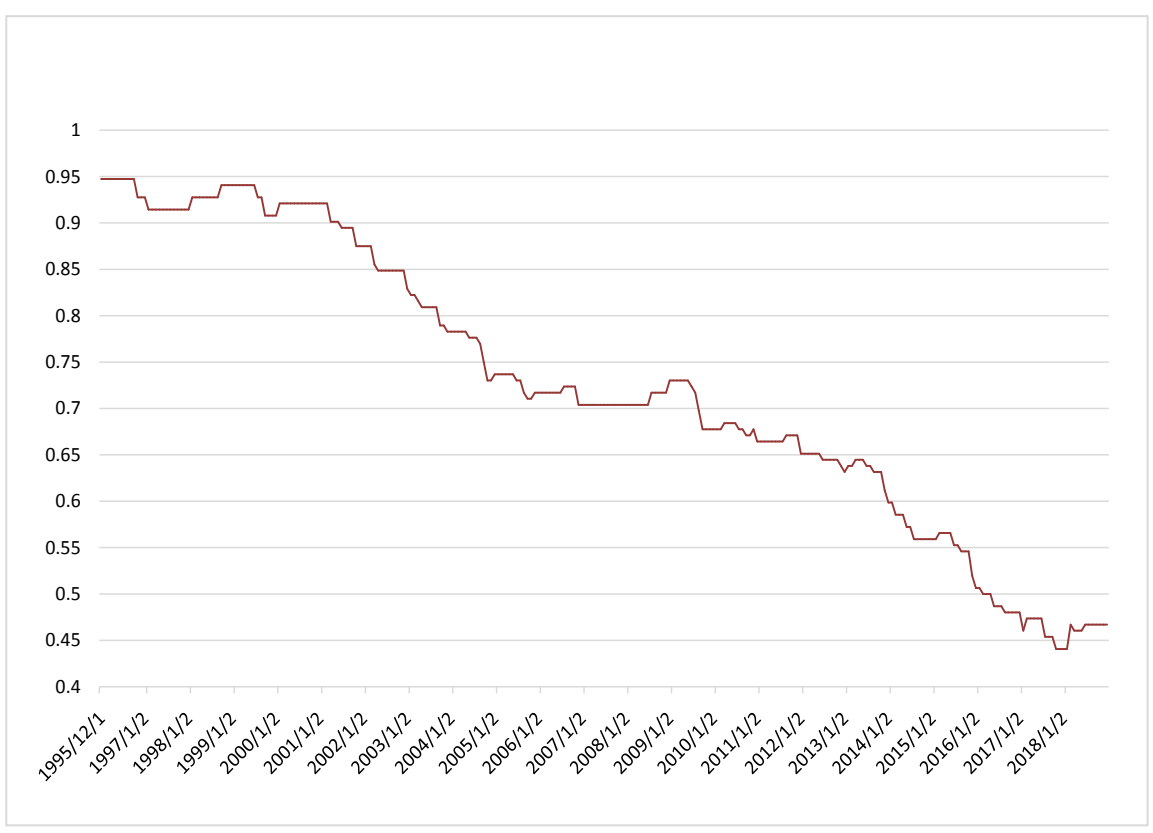

Figure 1. Monthly capital control intensity index. Source: IMF and State Administration of Foreign Exchange (SAFE).

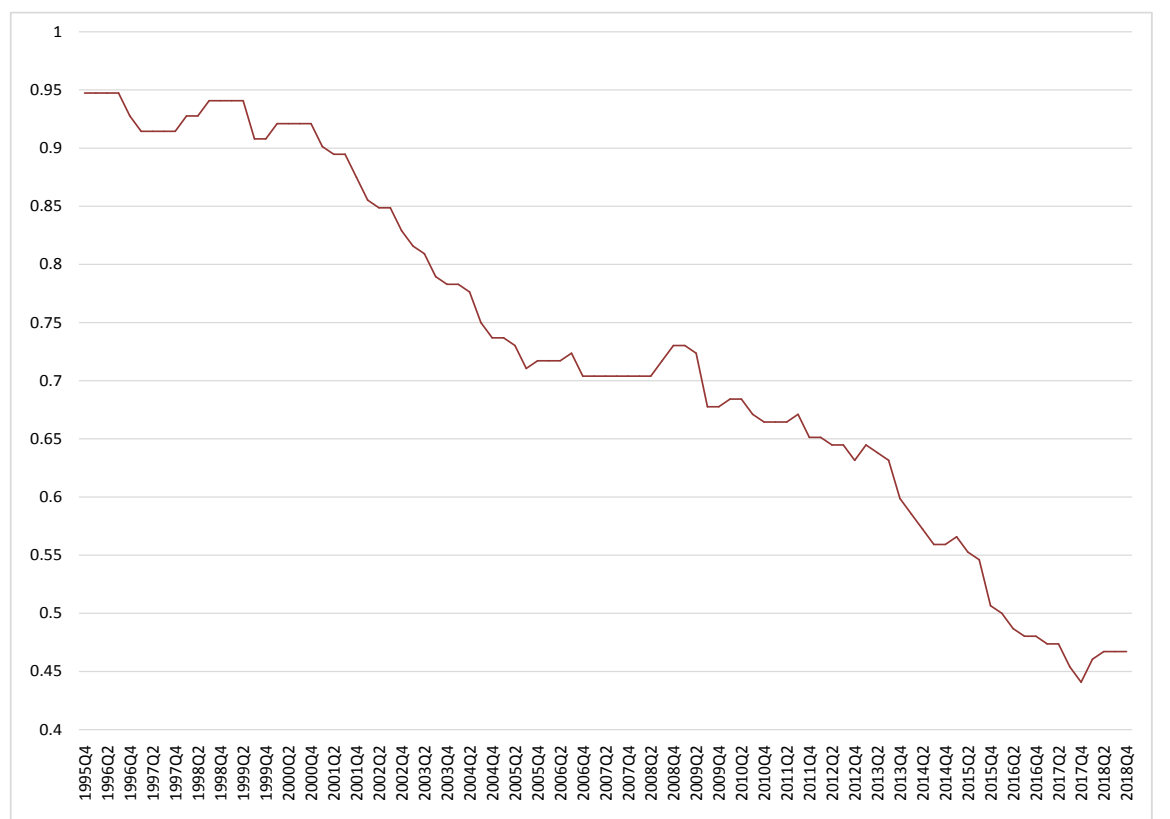

Figure 2. Quarterly capital control intensity index. Source: IMF and State Administration of Foreign Exchange (SAFE).

and it has brought huge threat on the stability of China's real economy and financial market. In order to avoid the further spread of the crisis in China and maintain the stability of the exchange rate, China introduced the measures such as banning the purchase of foreign exchange and paying back loans in advance to control the outflow of international capital, and slowed down the pace of capital account opening which made the intensity of capital control rise at this time. 
During the period of 1999-2006, the intensity of capital control showed a downward trend. In this period, with the rapid development of domestic economy, China has been deepening its contacts with the global economy. In 2003, CEPA agreement was signed in Hong Kong, which allowed the use of RMB for border trade for the first time, and marked the completion of the first step of internationalization development of renminbi. In 2004, the "going global" strategy was issued, which accelerated the pace of capital account liberalization.

In the financial market, the QDII and QFII mechanisms were introduced, and the cross-border securities market was deregulated substantially. Cross-border stock investment activities were also allowed. In addition, the management of foreign debt balance of commercial banks was tightened restrictions in 2000 .

In the aspect of direct investment, China stimulated the inflow of foreign investment by simplifying the examination and approval of capital sources, canceling the margin of profit repatriation and other ways on the process of examination and approval. In addition to the continuous deregulation of capital flow, in order to avoid the potential threat to the domestic market caused by the abnormal fluctuation of these capital flows during the process of capital liberalization, the government issued a number of normative policies in terms of capital activities' examination, approval and limitation, and intensified the supervision of cross-border capital activities, making the intensity of capital control in 1999-2006 a downward trend of volatility.

During the period of 2007-2015, the intensity of capital control also showed a fluctuating trend of decreasing, and had a obvious rise in 2008. In 2007, China's liberalization strategy of foreign exchange capital has achieved certain positive results, and the restrictions on the capital account projects, such as "securities market", "currency instruments market", "commercial and financial credit", and "foreign direct investment", have been relaxed to a certain extent. In this case, when the financial crisis happened in 2008, compared with the Asian financial crisis in 1997, China's domestic market was more closely connected with other countries, so the impact of the crisis was greater than before because international capital had more ways of inflow. On the other hand, after the subprime mortgage crisis, most of the developed countries have adopted quantitative and easing monetary policies, which have increased the global currency liquidity. As an emerging market country with high economic growth and stable domestic environment, China has become the main target of international speculative capital which increased the pressure of abnormal fluctuation of international capital in China. Therefore, in the face of this situation, China has begun to issue a number of policies to intensify the limit of the inflow and outflow of international capital, and increased the rate of advance receipt of foreign exchange in goods trade and reduce the quota of domestic securities investment that qualified foreign institutional investors fail to effectively use within two years. Therefore, the intensity of capital control was a significant increase in 2008. Since then, with the increase of the net error and missing term in 2011, China's State Administration of Foreign Exchange issued relevant policies to tighten the control of "guar- 
antee and financial support tools" item to reduce the scale of foreign guarantee balances of banking institutions for financing purposes. However, after the financial crisis, China's control of cross-border capital has generally declined. In 2010, in order to further promote cross-border capital flow, China relaxed the qualifications of the guaranteed, and expanded the scope of the bank's external guarantee business and further simplified the approval procedures. In 2014 and 2015, China launched the "Shanghai-Hong Kong Stock Connect" and "Mutual Recognition of Funds" between the mainland and Hong Kong. From 2007 to 2015 , it is also the stage of rapid development of RMB internationalization. At this stage, relevant policies are intensively issued, such as issuing RMB bonds in Hong Kong for the first time in 2007, setting up exchange rate department to develop RMB offshore market in 2008, signing currency swap agreements in Malaysia, Argentina, Indonesia and other countries in 2009, and intensively distributing RMB global clearing network in 2014 The international development of currency plays an important role in the work of capital account opening.

During the period of 2016-2018, the intensity of capital control also showed a trendy of decreasing and then increased in 2018. In 2016, RMB officially became one of special drawing right currency, and the central bank established the first RMB internationalization Research Center, which is a milestone for the development of RMB internationalization. In addition, in order to further expand the domestic capital market, QFII and RQFI systems were reformed in February and August 2016 respectively. In 2017, the "Bond Link" mechanism between Hong Kong and the mainland was established to promote the opening of the bond market between financial institutions. In 2018, the serious trade friction which brought great challenges to the stability of exchange rate, balance of payments and economic and financial development in China. In order to cope with this challenge and ensure the stability of international capital flow, the State Administration of Foreign Exchange successively issued a number of regulations to further regulate and tighten restrictions on internal guarantee and external loan, the sale of foreign exchange, and cross-border fund custody, etc. The State Administration of Foreign Exchange also prohibited foreign investors to remit RMB funds out of the country and purchase foreign exchange when they make overseas investment.

\subsection{Conclusion}

The intensity of China's capital control policy shows the trend of fluctuation decreasing and the restrictions relaxes gradually, and it is obviously influenced by the domestic economic environment and international factors. In this paper, there are 220 laws and regulations on international capital control since 1996 have been sorted out and measured, and can see that the change of China's cross-border capital control policy is a stable and gradual process, and the focus of the reform generally follows the opening principle. In addition, since the reform and opening-up, China's economic ties have become increasingly close to the world, and the intensity of regulation has increased significantly in both 1997 and 2008 when the crisis occurred. 


\section{Conflicts of Interest}

The author declares no conflicts of interest regarding the publication of this paper.

\section{References}

Ba, S. S., \& Ba, Q. (2019). International Experience and China's Exploration of Macro Prudential Management of Cross-border Capital Flows. Tsinghua Financial Review, 8 , 23-25.

Bayoumi, T. (1990). Saving-Investment Correlations: Immobile Capital, Government Policy, or Endogenous Behavior? International Monetary Fund Staff Papers, 37, 360-387.

Bekaert, G., Harvey, C. R., \& Lundblad, C. (2003). Equity Market Liberalization in Emerging Markets. Journal of Financial Research, 26, 275-299.

https://doi.org/10.1111/1475-6803.00059

Binici, M., Hutchiso, M., \& Schindler, M. (2010). Controlling Capital? Legal Restrictions and the Asset Composition of International Financial Flow. Journal of International Money and Finance, 29, 666-684. https://doi.org/10.1016/j.jimonfin.2010.01.001

Chinn, M. D., \& Ito, H. (2008). A New Measure of Financial Openness. Journal of Comparative Policy Analysis, 10, 309-322. https://doi.org/10.1080/13876980802231123

Edison, H. J., \& Warnock, F. E. (2003). A Simple Measure of the Intensity of Capital Controls. Journal of Empirical Finance, 10, 81-103. https://doi.org/10.1016/S0927-5398(02)00055-5

El-Shagi, M. (2012). Initial Evidence from a New Database on Capital Market Restrictions. Panoeconomicus, 59, 283-292. https://doi.org/10.2298/PAN1203283E

Epstein, G., \& Schor, J. (1992). Structural Determinants and Economic Effects of Capital Controls in OECD Countries. Oxford: Clarendon Press.

Feldstein, M., \& Horioka, C. (1980). Domestic Savings and International Capital Flows. NBER Working Paper, 90, 314-329.

Gou, Q., et al. (2012). Is China's Short-Term Capital Flow Control Effective? The Journal of World Economy, 2, 26-44.

Gwartney, J. D., Lawson, R., \& Block, W. (1996). Economic Freedom of the World, 1975-1995. Fraser Institute.

Huang, Y. P., \& Wang, X. (2010). An Analysis of the Effectiveness of Capital Account Control in China. Financial Development Review, 6, 107-134.

Jin, H. (2004). A Study on the Intensity of Capital Control in China. Journal of Financial Research, 12, 9-23.

Kraay, A. (1998). In Search of Macroeconomic Effect of Capital Account Liberalization. Unpublished, Washington: World Bank Working Paper.

Lane, P. R., \& Milesi-Ferretti, G. M. (2001). Long-Term Capital Movements. NBER Macroeconomics Annual, 16, 73-116. https://doi.org/10.1086/654435

Levine, R. \& Zervos, S. (1998) Stock Markets, Banks, and Economic Growth. The American Economic Review, 88, 537-558.

Quinn, D. P., \& Toyoda, A. M. (2007). Ideology and Voter Sentiment as Determinants of Financial Globalization. American Journal of Political Science, 51, 344-363. https://doi.org/10.1111/j.1540-5907.2007.00255.x

Zeng, S. L. (2015). Research on the International Short-term Capital Flow and the Effectiveness of China's Capital Control. Ph.D. Thesis, Hangzhou: Zhejiang University.

Zhang, C. S. (2016) IMF's Capital Flow Management Framework. Journal of Financial Research, 4, 13-45. 